\section{Marek Matejun}

(iD) https://orcid.org/0000-0003-4885-2344

Department of Entrepreneurship and Industrial Policy

Faculty of Management

University of Lodz, Lodz, Poland

marek.matejun@uni.lodz.pl
Maciej Woźniak ${ }^{1}$

iD https://orcid.org/0000-0001-8520-6443

Department of Economics, Finance, and Environmental Management

Faculty of Management

AGH University of Science

and Technology in Cracow, Poland

mwozniak@zarz.agh.edu.pl

\title{
Strategic determinants of the support absorption process in the SMEs sector companies
}

Accepted by Editor Ewa Ziemba | Received: March 16, 2020 | Revised: July 17, 2020; July 21, 2020 | Accepted: July 22, 2020.

\begin{abstract}
Aim/purpose - The aim of the paper is to identify and assess the strategic factors that determine the absorption process of support instruments by SMEs sector companies.

Design/methodology/approach - Strategic factors were identified on the basis of the literature review and opinions of ten experts representing management sciences. Further empirical verification of the proposed assumptions was carried out on a random sample of 1,741 micro-, small- and medium-sized enterprises from 22 European Union countries.

Findings - The obtained results indicate a significant positive influence of five identified strategic factors, i.e. social, support environment, resource, management system and organisational, on the support absorption process. This impact is slightly stronger in the acquisition phase than in the use of support instruments by the SMEs.

Research implications/limitations - The results provide a basis for improving efforts to acquire and use external support for micro-, small- and medium-sized enterprises. The limitations of the study include respondents' high subjectivity of opinions and complex character of considered theoretical constructs.

Originality/value/contribution - The contribution of research to the development of management sciences primarily includes the formulation and empirical verification of a set of strategic factors determining the support absorption process in SMEs.
\end{abstract}

\footnotetext{
1 Names are provided in the alphabetical order. The contribution of each author to the preparation of the paper is $50 \%$.
}

Cite as: Matejun, M., \& Woźniak, M. (2020). Strategic determinants of the support absorption process in the SMEs sector companies. Journal of Economics \& Management, 41(3), 5-24. https://doi.org/10.22367/jem.2020.41.01 
Keywords: small business, SMEs sector, support, absorption process, entrepreneurship, strategic management.

JEL Classification: L10, L25, L26.

\section{Introduction}

The issue of creating appropriate conditions for the development of micro-, small- and medium-sized enterprises (SMEs) has been in focus of the European Union countries, including Poland, for many years. For this purpose various support instruments have been offered by specific institutions as part of regional, national or international initiatives and assistance programmes. These activities are the subject of many scientific studies (Peszko, 2013, 2014ab; Woźniak, 2012ab, 2014abc). An important direction of this research is the issue of absorption that means acquiring and using the support directly by companies from the SMEs sector. The course of the absorption processes is of key importance for both entrepreneurs and small business support institutions. It also allows understanding and explanation of the reasons for the low effectiveness of some of the programmes and aid initiatives being implemented. However, most of the recent research has focused on the specific nature of different support programmes and instruments (e.g. Moritz, Block, \& Heinz, 2016; Ozekicioglu \& Yetiz, 2019), on the outputs of support initiatives (e.g. Benkkovskis, Tkačevs, \& Yashiro, 2019; Ciszewska-Mlinarič, 2018; Radicic \& Pugh, 2017) or on the barriers to support absorption by SMEs (Beizitere \& Brence, 2020; Szara, 2012; Wach, 2008). Nevertheless, the key (strategic) factors determining the acquisition and effective use of support in SMEs development processes were analysed to a much smaller extent. This indicates the existence of a specific research gap which justifies addressing the research problem presented in this paper.

Taking this into account, the aim of the paper is to identify and assess the strategic factors that determine the absorption processes of support instruments by SMEs. The aim of the work was accomplished by carrying out the empirical research by the authors, using the survey method on a random sample of 1,741 micro, small and medium enterprises from the area of 22 European Union countries. The strategic factors were identified on the basis of the literature review and the Delphi survey, which involved 10 experts representing the management science community. The results show a significant beneficial effect of five strategic areas: social, support environment, resource, management system and organisational on the course of absorption of the support. However, the effect is slightly stronger in the phase of acquisition than the use of the support instruments by SMEs. 
The structure of the paper is as follows. First, the literature is reviewed and research gap is identified. Then, the methodology is described. The research findings are delivered in section 4 . The paper ends with the discussion and conclusions.

\section{Literature review}

As noted by Jelonek (2016, p. 58), there are a number of interesting research problems related to the absorption process, which in general, means the ability to permanently introduce resources occurring in the business environment to the organisational system with the intention of using them to achieve specific goals. Research in this field may concern, among others, development of new products, creation and effectiveness of innovation, absorption of knowledge or technology. Absorption is also a term widely used in economic science to describe the challenges associated with the acquisition and use of support in the economy. It may concern the activity within:

- macroeconomic situation, considered as the ability of the recipient country to its effective use (Kopiński, 2011, pp. 186-189),

- mesoeconomic situation, most often implemented by local government units in order to use support in stimulating development at the regional or sectoral level (Biczkowski \& Jezierska-Thole, 2010, pp. 13-24),

- microeconomic situation, related to the acquisition and use of specific support instruments by specific enterprises and other types of organisation.

A special group of enterprises interested in absorption activity are micro-, small- and medium-sized enterprises, for which various assistance initiatives are undertaken and specific instruments for support development are offered. In general, they are divided into financial and non-financial (Lisowska \& Stanisławski, 2011, p. 292), while a broader review of the literature allows for distinguishing such support instruments for SMEs (Woźniak, 2012a , pp. 73-75) as:

- non-returnable financing, e.g., grants from EU funds,

- external financing, e.g. loans, leasing or sureties,

- equity financing, e.g. the involvement of private equity investors,

- administrative and legal, e.g. tax exemptions or investment allowances,

- consulting, training and information for SMEs,

- technological and pro-innovation, e.g. technology audit or transfer,

- organisational or business, e.g. an offer of entrepreneurship incubators or technology parks. 
Factors determining the possibilities of obtaining and using these support instruments by SMEs can be divided into internal, having their source in the enterprise itself, and external, related to the entire support system as a part of the business environment. In case of financial support provided in the form of grants, the following factors need to be accounted for (Brodzińska \& Brodziński, 2010, p. 12; Godek, 2008, p. 27; Kołodziej-Hajdo \& Surowiec, 2001, p. 542): need to ensure equity, requirements of the application procedure, documentation of the development activities undertaken and their implementation, waiting period for fund reimbursement or preparation of the application for payment and settlement of subsidies. With non-financial support, the key factors of non-financial support include (Vedovello \& Godinho, 2003, p. 17; Woźniak, 2014b, pp. 44-47, 2014c, pp. 396-397): infrastructure, purpose and scope of activity of the institution providing support (for-profit, non-profit), adaptation of the offer to the needs of entrepreneurs or cooperation between organisations providing support.

Lisowska (2014, p. 20) while examining the opinions of entrepreneurs on the conditions of obtaining and using financial and non-financial support by SMEs in business practice, additionally draws attention to the factors affecting absorption, such as information about business environment institutions, knowledge about potential benefits and threats of using the support, quality and adjustment of support to the needs of a company, as well as the possibility of using support in the development processes of a company.

The complexity of these factors means that entrepreneurs assess support initiatives in various ways. Woźniak (2012b, pp. 177-178), based on the results of his research, states that subsidies for investments and innovations, tax reliefs and exemptions, as well as preferential loans and credits have the highest rank. These factors also determine the course of the support absorption process, which includes specific activities necessary to be undertaken and implemented by the SMEs sector companies in order to effectively obtain and use support in development processes. This process can be divided into two general phases (support acquisition and use) and seven detailed stages covering (Matejun, 2015, p. 79):

1. In the phase of acquiring the support:

- identification and assessment of support instruments existing in the external environment,

- adaptation to the requirements of business environment institutions and conditions for the absorption of support,

- application for support,

- assimilation, including the introduction of support to the organisational system of a company. 
2. In the phase of using the support:

- exploitation - using support aimed at achieving the set goals,

- evaluation, including assessment of the effectiveness of acquiring and using support,

- accumulation of knowledge and experience from absorption activity for future use.

The literature indicates that many difficulties arise in the absorption processes of SMEs. Szara (2012, p. 175, 179-182) analyses the taxonomy of the most common barriers encountered by beneficiaries of public aid in Poland. In the phase of gaining support, for example, there may be problems related to employees who are involved in the preparation of an application or external consulting companies that offer such a service. In the implementation phase, she distinguishes 12 barriers that most often arise, among others, interpersonal conflicts, management style or organisational structure. An unquestionable advantage of the approach presented by her is an extensive analysis of many areas affecting the acquisition of support instruments and their connection with various stages of this process. In this case, however, there is no wider empirical verification based on appropriate quantitative research.

Marshall et al. (2020, pp. 1, 3-6) based on research in three sectors: manufacturing, high-tech and services in the UK, make a proposal for the dimensions of knowledge absorptive capacity in SMEs. They distinguish: acquisition, assimilation, transformation and exploitation. The conclusion is that one must understand SMEs that are 'innovation followers' and those that have sustainability orientations. Moreover, some companies recognise an innovation as necessary for business sustainability. The study is restricted to only four locations and three sectors.

Wach (2008, pp. 138-142), using statistical methods, points to barriers that determine low assessment of support instruments by entrepreneurs in Poland. His results indicate that the majority of the SMEs surveyed assessed the instruments as bad or very bad. This is mainly due to the lack of developmental needs and information about the availability of assistance initiatives. Other reasons, such as too high costs and unmatched support offer, were not so important. $\mathrm{He}$ also indicates the existence of a relationship between: the age of a company, its size and the entrepreneurial attitude of the owner, and the use of the offer of small business environment institutions. The results of these studies were narrowed, however, to the area of two provinces (Małopolskie and Śląskie). 
Prokop \& Stejskal (2019, pp. 134-145) focus on SMEs absorption of innovation in Germany. They state that it is mainly connected with entrepreneurial environment, globalisation and fast changing technological issues. They also set two important questions: whether support policies focused on the right beneficiaries from SMEs sector and their innovation activity and whether companies consider public schemes to be beneficial and do they intend to use them despite the bureaucracy. The study, however, does not give any recommendation for the current present.

De Jesus Pacheco, ten Caten, Jung, Ribeiro, Navas, \& Cruz-Machado (2017, pp. 2277-2287) find key determinants of eco-innovation in manufacturing SMEs. The research is based on systemic review covering 24 years. The external critical determinants are support and neutrality of regulatory policies regarding SMEs and large enterprises. However, the scale of support for innovative strategies and availability of resources such as people or technology are crucial in internal context. The research is restricted to search criteria adopted, therefore some databases or dissertations are missing.

The review of the literature and the results of existing research indicate the existence of many proposals of factors determining the support absorption process by SMEs. However, some of these approaches are fragmentary and focus on analyses narrowed to specific macroeconomic conditions, specific aid instruments, cover only selected locations or chosen sectors, or even companies. Therefore, there is a research gap in an approach aimed at identifying and assessing strategic factors determining the absorption processes of various support instruments by SMEs. This issue was the subject of research, the results of which are presented in the further part of the paper.

\section{Research methodology}

The research process aimed at achieving the goal of the paper consisted of two stages: (1) expert research using the Delphi method and (2) survey research. In the first part of the research, the strategic factors determining the absorption activity of SMEs were identified. The opinions of 10 experts representing the field of science in the area of SMEs management and/or strategic management were selected on the basis of criteria: scientific, substantive and impact were used for this purpose. These opinions were formulated and evaluated in the framework of a 3-round Delphi survey, the aim of which was to obtain a high level of experts' compliance ${ }^{2}$.

2 For more detailed information on the methodology, course and results of the Delphi survey see Matejun's paper (2015, pp. 141-168). 
The second part of the research was devoted to a quantitative survey conducted on a random sample of 1,741 SMEs. Computerized Self-Administered Questionnaire was used as a research technique (Bryman \& Bell, 2015). The research questionnaire was available to respondents at www.questionpro.com. Due to the fundamental importance of the SMEs for the socio-economic development of the European Union (Muller, Devnani, Julius, Gagliardi, \& Marzocchi, 2016) and due to undertaking many support initiatives for these entities (Florio, Vallino, \& Silvia, 2017; McCann \& Ortega-Argilés, 2016) 22 EU countries were designated for the research: Austria, Belgium, Bulgaria, Croatia, the Czech Republic, Denmark, Finland, France, Greece, Spain, the Netherlands, Lithuania, Germany, Poland, Portugal, Romania, Slovakia, Slovenia, Sweden, Hungary, Great Britain, Italy. Statistical data (Eurostat data, 2017; The SME Performance Review data, 2016) indicate that over 21 million enterprises operate in this area, of which over $98 \%$ are SMEs.

The research covered 1,183 micro enterprises (68\%), 399 small companies (23\%) and 159 medium-sized enterprises (9\%). The size of entities was determined on the basis of a uniform formal definition of SMEs applicable in the European Union (Wach, 2004). The obtained sample size ensures statistical representativeness of the obtained results (Keller, 2012, pp. 354-356) in relation to the adopted number of SMEs in the EU (for 2015) of 22,959,600 entities (Muller et al., 2016, p. 77), taking into account the maximum allowable estimation error $\mathrm{d}=+/-0.0235$ at the assumed level of significance $\mathrm{p}=0.05$.

Most of the surveyed enterprises operate as sole traders (45\%) or limited liability companies (LLCs) (35\%). These are mainly service enterprises (60\%), less often operating in the production sector $(21 \%)$ or trade $(19 \%)$. The majority of surveyed companies (73\%) are active on the market at least on a national scale, of which $35 \%$ internationalise their activities. The sample included both mature entities with a market activity period of over 20 years (36\%) as well as companies with a business period of 5 to 10 years (21\%). The empirical material from the surveyed enterprises was collected based on the judgments of the respondents. They were primarily owners (74\%), less often senior managers (19\%) or employees authorised by management to participate in the research (7\%). The questions were answered mainly by men (70\%), people aged from 31 to 40 $(30 \%)$ or over $50(36 \%)$, with higher education $(81 \%)$ in technical $(40 \%)$ or economic/managerial field (26\%). 


\section{Research findings}

In the first part of the research specific groups of SMEs absorption factors were designated on the basis of expert opinions. Based on their statements formulated in the 1st round of the study, 36 properties describing strategic approach of SMEs to support absorption were determined and presented for evaluation in the next stages. The results obtained in stage 2 and 3 provided foundations for an appropriate level of consensus among the experts and made it possible to identify the following five groups of strategic factors:

1. Social factors related to the role of the personnel functions aimed at involving the staff in the support absorption (e.g. in the area of motivation, development of staff competence, or the system of evaluation and control), leadership of entrepreneurs and managers in the support absorption process as well as conducting the absorption activities in an ethical and socially responsible manner.

2. Factors related to support environment, including recognition and knowledge about the conditions for the acquisition and effective use of various support instruments and the ability to objectively assess the costs, benefits and risks of using support in the company development processes.

3. Resource factors related to the ability to mobilise and concentrate company tangible and intangible resources on absorption activities and the involvement of managers and employees in the absorption process of various support instruments. Furthermore, resource surpluses are of importance as they allow for company's quick response to the support opportunities.

4. Factors in the area of management system, including targeting support for the implementation of strategic directions of an enterprise development, adapting them to the pace, objectives and situation of the company as well as the ability to acquire and effective use of support quicker than competitors.

5. Organisational factors, including the ability of introducing formal organisational solutions necessary to acquire and use support (e.g. the designation of an organisational unit or a manager responsible for absorption activity) as well as the occurrence of informal conditions for a creative and inspiring approach to the acquisition and use of various support instruments in company development processes (e.g. sharing knowledge, experience and ideas related to absorption activities).

In order to assess the impact of these factors on the absorption activities of companies from the SMEs sector, further quantitative research was carried out, on a wide sample of micro-, small and medium enterprises. First, the scope of 
using support by the analysed entities in the last 2 years was assessed. A 4-point order scale was used with a range from 0 (no use of support) to 3 (use of support in a very large range in relation to the needs of a company). Activity absorption was assessed in relation to particular types of support instruments, including: administrative and legal, advisory, training and information, technological, and organisational and business as well as non-repayable financing, external financing, equity financing. In order to obtain more precise answers, each type of support was provided with an appropriate comment together with examples of aid instruments.

On the basis of individual responses, a synthetic index was calculated for each entity expressing the general attitude of the surveyed enterprises for using support in development processes (SD). This indicator was the arithmetic mean of the scope of using particular forms of support. The Cronbach alpha coefficient (Cronbach \& Shavelson, 2004) was used to assess the level of reliability of this index, which amounted to 0.730 . This result falls within a statistically acceptable range $>0.7$ (Sarstedt \& Mooi, 2014). The results obtained indicate that the surveyed companies use support in a very small scope in relation to their needs, because the average level of $\mathrm{SD}=0.76$, which is only $19 \%$ of the range of scale variation. The external financial support is used in a relatively greater range (average 1.21), advisory, training and information (1.16) and non-repayable financing (0.93). However, organisational and business support (0.46) and equity financing (0.22) were used in the relatively smallest range, which is connected with the fact that the owners want to maintain full control over the company.

In the second part of the research, the support absorption process in the surveyed companies was assessed. A negative assessment was used to determine the difficulties arising at each stage, expressed on a visual analogue scale (VAS) (Reips \& Funke, 2008) in the range from 0 (no difficulty) to 100 (very serious difficulties). The obtained results indicate that respondents identify moderate difficulties (45 on average), with relatively higher levels reaching the acquisition stage of support (50 on average), including identification stage (53), adaptation (51) and application for support (54). The difficulties arising in the phase of using the support (38 on average), including at the exploitation stage (39), evaluation (39) and accumulation (37), were assessed much lower. Difficulties arising at the assimilation stage (included in the support acquisition phase) also reached a relatively lower value of 41 . Taking into account these results, three synthetic measures expressing the level of difficulty were constructed: (1) difficulties in the process of absorbing support in total (DT), (2) difficulties in the 
phase of support acquisition (DA) and (3) difficulties in the phase of using the support (DU). These indicators constitute the arithmetic average of the difficulty assessments at individual stages. The assessment of the reliability of the scales with the help of Cronbach's alpha coefficient obtained acceptable levels: alpha Cr. (DT) $=0.921$, alpha Cr. $(\mathrm{DA})=0.890$ and alpha Cr. $(\mathrm{DU})=0.894$. The results also indicate that the level of difficulty of DT decreases significantly with an increase in the extent of absorption: $r_{x y}(n=1,741)=-0.25, p<0.01$, which is associated with increasing experience of companies in obtaining and using support.

Next, the range of occurrence of strategic determinants of the identified absorption activity course, in the expert study, was assessed. On the basis of expert opinions, every factor was translated to 2 or 3 dimensions (11 dimensions in total), assessed by respondents in quantitative studies on a scale (VAS) in the range from 0 (definitely disagree) to 100 (definitely agree). All the factors obtained acceptable levels of reliability scale measured by the alpha Cr. coefficient between 0.743 and 0.853 . Their values ranged from 43 to 62 , the highest value was obtained by social factors, and the lowest by resource and organisational factors.

As the support absorption by SMEs is strongly related to the potential of the business environment, in addition, the considerations include external factors related to the assessment of conditions for the development of entrepreneurship in which the surveyed companies operate. They were divided into subjective and objectified factors. The subjective factors are related to the assessment of the support activity of organisations and the availability of various support instruments by the respondents. They have been operationalised using a synthetic measure consisting of six indicators expressing, among others, conditions offered to support the activity of the local environment in the activities of absorption and stability as well as the attitude of the national support system toward SMEs, diversity and activity of small business environment institutions. The analysis of the reliability scale revealed an acceptable level of the alpha Cr. = 0.877 , and the average rating on the scale from 0 to 100 was only 27 . An objective evaluation of the support segment was made on the basis of a synthetic index consisting of seven dimensions concerning, i.a. access to finance for SMEs, public support programmes for small businesses, $R \& D$ and technology transfer as well as commercial support institutions for SMEs. Their level was determined based on the results of the panel of national entrepreneurial experts (NES) as part of the Global Entrepreneurship Monitor (Amorós \& Bosma, 2014) and disseminated to the range from 0 (worst conditions) to 100 (the best condition for the development of entrepreneurship). The average result was 38 . 
Based on the set of adopted variables, a multiple regression analysis was carried out to assess the impact of strategic absorption factors and the conditions for entrepreneurship development on the process of support acquisition and use by the surveyed SMEs. The results are shown in Table 1.

Table 1. Analysis of the impact of strategic absorption factors on the process of acquisition and using support by SMEs

\begin{tabular}{|c|c|c|c|c|}
\hline & Variables & Model 1 & Model 2 & Model 3 \\
\hline & Dependent variable & $\begin{array}{l}\text { Difficulties in the } \\
\text { process of absorbing } \\
\text { support in total }\end{array}$ & $\begin{array}{l}\text { Difficulties in the } \\
\text { phase of support } \\
\text { acquisition }\end{array}$ & $\begin{array}{l}\text { Difficulties in the } \\
\text { phase of support } \\
\text { use }\end{array}$ \\
\hline \multirow{7}{*}{ 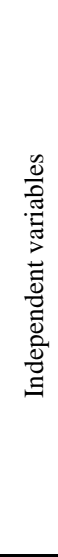 } & Social factors & $-0.13 * *$ & $-0.08 * *$ & $-0.18 * *$ \\
\hline & $\begin{array}{l}\text { Factors related to the support } \\
\text { environment }\end{array}$ & $-0.20 * *$ & $-0.21 * *$ & $-0.16^{* *}$ \\
\hline & Resource factors & $-0.12 * *$ & $-0.14 * *$ & $-0.08 *$ \\
\hline & $\begin{array}{l}\text { Factors in the area of the } \\
\text { management system }\end{array}$ & $-0.09 * *$ & $-0.09 * *$ & $-0.07 *$ \\
\hline & Organisational factors & $-0.07 *$ & $-0.09 * *$ & -0.04 \\
\hline & $\begin{array}{l}\text { Subjective assessment } \\
\text { of conditions for } \\
\text { entrepreneurship development }\end{array}$ & -0.01 & -0.04 & 0.05 \\
\hline & $\begin{array}{l}\text { Objectivised evaluation } \\
\text { of conditions for } \\
\text { entrepreneurship development }\end{array}$ & $-0.07 * *$ & $-0.06^{* *}$ & $-0.07 * *$ \\
\hline \multicolumn{2}{|c|}{ Number of observations } & 1741 & 1741 & 1741 \\
\hline \multicolumn{2}{|c|}{$\mathrm{R}^{2} / \mathrm{R}^{2}$ corrected } & $0.27 / 0.27$ & $0.29 / 0.29$ & $0.19 / 0.19$ \\
\hline \multicolumn{2}{|c|}{ F statistics } & $93.53 * *$ & $100.34 * *$ & $56.97 * *$ \\
\hline
\end{tabular}

$* \mathrm{p}<0.05 ; * * \mathrm{p}<0.01$. Multiple regression analysis. The table presents the values of standardised coefficients.

Source: Own study based on the results of survey research.

Three models were chosen for the analysis, in which the following difficulties were assumed as dependent variables: (1) in the overall absorption process, (2) in the support acquisition phase, and (3) in the support use phase. All models turned out to be statistically significant, and the analysis showed a significant impact of the identified strategic factors on reducing difficulties in the process of absorbing support by the surveyed companies. The analysis of the coefficient of determination indicates that the impact is stronger at the acquisition stage than the use of support. 


\section{Discussion}

The results achieved are consistent with specific findings from many existing research studies. They confirm that the SMEs surveyed use support in very small scope in relation to their development needs. Low support absorption activity by small business has been observed for many years both in Polish (e.g. Borowiecki \& Siuta-Tokarska, 2008, pp. 264-268) and European research (European Central Bank, 2014). This problem has been stressed in recent years by, among other, Lisowska (2017), who indicated that only $28.5 \%$ of surveyed SMEs (out of 353 companies) received support from business environment institutions. What is interesting, small scope of support use also concerns innovative SMEs, which constitute a group to which a significant part of aid programmes and institutional offer is addressed (Cyran, 2016).

One of the factors of low absorption activity of SMEs are numerous barriers to the support use, which has also been the subject of many previous studies (e.g. Szara, 2012; Wach, 2008). These barriers include, among others, attention to the selectivity of public support (North, Smallbone, \& Vickers, 2001), unequal access of SMEs to aid programmes, insufficient information on forms of financial support (Borowiecki, Siuta-Tokarska, Thier, \& Żmija, 2018), as well as many formal and systemic barriers (Sawicki, 2019). Such barriers were also identified in the research presented in this paper, with an innovative approach to their analysis including the division into two groups related to: (1) acquisition and (2) use of the support. Moreover, it was observed that the level of difficulty decreases significantly with an increase in the extent of absorption. This is consistent with the findings of Braidford \& Stone (2016) who indicated that the experience gained through long and diverse history of business-support usage increases interest and efficiency in the use of support in small business development processes.

However, the novel contribution of the achieved research results to the development of management sciences includes the identification and assessment of strategic factors determining the absorption of support in SMEs development processes. The key determinants turned out to be factors related to the support environment, including the development of knowledge about the support availability and costs, benefits and threats resulting from the use of various support instruments. In the phase of support acquisition, companies should pay particular attention to the mobilisation and concentration of resources and ensure the involvement of managers and employees in absorption activities. In the phase of 
using the support, the social aspect was very important, mainly due to the leadership of owners in the absorption activities as well as the acquisition and utilisation of support in an ethical and socially responsible manner, which has a beneficial effect on building long-term and partner relationships with the support segment. The factors related to the management and organisational system play a smaller role in the process of support absorption, especially in the phase of its use. This is due to the qualitative features of companies from the SMEs sector that generally apply simplified management methods and simplified organisational solutions, which particularly concerns the smallest companies. However, the internal strategic factors are complemented by appropriate conditions for the development of entrepreneurship and the applied infrastructure and institutional solutions in the support system. The results indicate that objectified factors play an important role here, being a consequence of strategic assumptions adopted and implemented at the national and regional level in the field of small business support policy.

The proposed approach develops and significantly improves the results of existing studies, which were fragmentary in their scope. Prior research of Han $\&$ Benson (2009) concentrated on such factors determining the support absorption SMEs as company characteristics (e.g. size, resources) and owner characteristics (e.g. gender, education, business experience). Johnson, Webber, \& Thomas (2007) analysed the impact of the company's location, engagement in R\&D activities and firm's orientation toward growth on the scope of external business advice services usage. Similar factors (e.g. size of the company, sector activity, entrepreneur gender, management orientation toward the growth) were also analysed by Mole, North, \& Baldock (2016). However, this study took into account the SMEs demand for support and their desire to solve development problems with the use of external support as factors influencing on absorption activity in the small business practice. Prior studies were also more concentrated on the operational factors of support usage, e.g. communication of entrepreneurs with advisors and support institutions (Mole, Hart, \& Roper, 2014).

Therefore, the weakness of the previous research is the lack of a more comprehensive approach to the identification and assessment of key (strategic) factors determining the course of support absorption in SMEs. This gap is filled by a set of strategic factors determining the support absorption in SMEs development processes identified on the basis of the research results presented in this paper. This integrated approach provides a basis for improving efforts to acquire and use external support for micro, small and medium-sized enterprises. It also 
makes possible to obtain an absorption pension (cf. Czakon, 2015; Niemczyk, 2013) related to the advantage over other enterprises in the area of the ability to effectively identify and use opportunities emerging in the support segment in the long term perspective.

\section{Conclusions}

The study showed a beneficial effect of strategic factors identified to facilitate and improve the course of an acquisition and use of support instruments by firms from SMEs sector. These determinants include five groups of strategic factors: social, support environment, resource, management system and organizational. However, business environmental factors also play an important role, including shaping a suitable climate for the development of entrepreneurship in a given area.

The obtained results indicate that the proposed approach explains about $30 \%$ of the volatility in terms of difficulties arising in the acquisition phase and about $20 \%$ of difficulties arising in the support use phase. This indicates the existence of a number of additional determinants of the process of support absorption, not considered in the framework of this research. Further analyses should therefore be aimed at searching for specific factors determining the course of the absorption process, taking into account the diversity of the acquired support instruments. However, this requires a transition from the strategic level to the operational level and perhaps to carry out additional ethnographic research based on a qualitative research approach.

When implementing the presented solutions, the limitations of the conducted tests should be taken into account (Geletkanycz \& Tepper, 2012). They mainly result from the use of an inductive study approach (Popper, 2014) and the survey research as the research method (Nardi, 2018). First of all, they include the high subjectivity of opinions of respondents and the multidimensional character of the theoretical constructs under consideration, which may be understood in various ways by the participants of the study. The problem is also the declarativeness of the answers provided by respondents with no guarantee that the barriers and factors analysed are actually found in the surveyed companies.

These analyses certainly require to be continued, which will allow for further, more detailed results and conclusions. Further promising directions of research include, in particular: identification and assessment of mediators and moderators of the impact of strategic determinants recognised in this study in the 
process of support absorption in SMEs sector companies as well as identification and assessment of specific operational factors determining the absorption of various forms of support by SMEs sector companies. It is also worth considering the extension of the quantitative analysis with case studies of SMEs with successes and failures (good and bad practices) in absorption activity. A practical implication of this research may be the preparation of diagnostic tests which will allow the assessment of strategic readiness of SMEs to obtain and effectively use support in development processes.

\section{References}

Amorós, J. E., \& Bosma, N. (2014). Global Entrepreneurship Monitor 2013. Global report: Fifteen years of assessing entrepreneurship across the globe. London: Global Entrepreneurship Research Association.

Beizitere, I., \& Brence, I. (2020). The use of public financial support: Study of microenterprises. Proceedings of the 2020 International Conference 'Economic Science for Rural Development' 53, 156-164. Retrieved from http://www.esaf.llu.lv/sites esaf/files/files/lapas/Krajums_Nr_53_07.07.2020.pdf. https://doi:10.22616/ESRD. 2020.53.018

Beņkovskis, K., Tkačevs, O., \& Yashiro, N. (2019). Importance of EU regional support programmes for firm performance. Economic Policy, 34(98), 267-313. https:// doi:10.1093/epolic/eiz003

Biczkowski, M., \& Jezierska-Thole, A. (2010). Wpływ absorpcji środków unijnych na rozwój rolnictwa regionu kujawsko-pomorskiego na przykładzie PROW [The influence of absorption of EU funds on the development of agriculture in the Kujawsko-Pomorskie region on the example of RDP]. Zeszyty Naukowe Szkoty Głównej Gospodarstwa Wiejskiego w Warszawie. Problemy Rolnictwa Światowego, 10/25(1), 13-24.

Borowiecki, R., \& Siuta-Tokarska, B. (2008). Problemy funkcjonowania i rozwoju matych i średnich przedsiębiorstw w Polsce. Synteza badań i kierunki działania [Problems of functioning and development of small and medium-sized enterprises in Poland. Synthesis of research and directions of activities]. Warszawa: Difin.

Borowiecki, R., Siuta-Tokarska, B., Thier, A., \& Żmija, K. (2018). Rozwój matych $i$ średnich przedsiębiorstw w Polsce wobec wyzwań gospodarki XXI wieku. Kontekst ekonomiczno-zarzadczy [Development of small and medium-sized enterprises in Poland in the face of the 21st century economy challenges. Economic and management context]. Kraków: Wydawnictwo UE.

Braidford, P., \& Stone, I. (2016), Providing business support to SMEs - how to encourage firms' engagement. Public Government / Zarzadzanie Publiczne, 4(38), 45-61. https://doi:10.15678/ZP .2016.38.4.04 
Brodzińska, K., \& Brodziński, Z. (2010). Skala i zakres wsparcia sektora małych i średnich przedsiębiorstw w ramach działań Regionalnego Programu Operacyjnego Warmia i Mazury [Scale and scope of support for small and medium-sized enterprises within the framework of the Regional Operational Programme for Warmia and Mazury]. Zeszyty Naukowe Wyższej Szkoły Bankowej w Poznaniu, Rozwój lokalny i regionalny: innowacyjność i rozwój przedsiębiorczości, 27, 11-19.

Bryman, A., \& Bell, E. (2015). Business research methods. Oxford: Oxford University Press.

Ciszewska-Mlinarič, M. (2018). Export intensity, geographic diversification and the role of public support: The evidence from Old and New Europe SMEs. Entrepreneurial Business and Economics Review, 6(2), 45-69. https://doi:10.15678/EBER.2018.060203

Cronbach, L. J., \& Shavelson, R. J. (2004). My current thoughts on coefficient alpha and successor procedures. Educational and Psychological Measurement, 64(3), 391-418. https://doi:10.1177/0013164404266386

Cyran, K. (2016). Ograniczenia wdrażania działań innowacyjnych w sektorze małych i średnich przedsiębiorstw [Limitations of the innovative activities implementation in small and medium enterprises]. Studia Ekonomiczne. Zeszyty Naukowe UE w Katowicach, 276, 197-209.

Czakon, W. (2015). Sieci międzyorganizacyjne w naukach o zarządzaniu - w kierunku sieciowych modeli biznesu [Interorganizational networks in management sciences towards networked business models]. Studia Ekonomiczne. Zeszyty Naukowe Uniwersytetu Ekonomicznego w Katowicach, 217, 9-18.

European Central Bank. (2014). Survey on the access to finance of small and medium-sized enterprises in the euro area. Frankfurt am Main: Author.

Eurostat data. (2017). Retrieved from http://epp.eurostat.ec.europa.eu

Florio, M., Vallino, E., \& Silvia, V. (2017). How to design effective strategies to support SMEs innovation and growth during the economic crisis: Lessons from ex-post evaluation of 2007-2013 ERDF programmes. European Structural \& Investment Funds Journal, 5(2), 99-110.

Geletkanycz, M., \& Tepper, B. J. (2012). Publishing in AMJ-Part 6: Discussing the implications. Academy of Management Journal, 55(2), 256-260. https://doi:10. 5465/amj .2012.4002

Godek, K. (2008). Efektywność wykorzystania funduszy strukturalnych Unii Europejskiej w Polsce [Efficiency of the use of European Union structural funds in Poland]. Studenckie Prace Prawnicze, Administratywistyczne i Ekonomiczne, 5, 23-35.

Han, L., \& Benson, A. (2010). The use and usefulness of financial assistance to UK SMEs. Environment and Planning C: Government and Policy, 28(3), 552-566. https://doi:10.1068/c0985b

Jelonek, D. (2016). Zdolność absorpcji wiedzy a innowacyjność małych i średnich przedsiębiorstw [Ability to absorb knowledge and innovativeness of small and medium enterprises]. Studia Ekonomiczne. Zeszyty Naukowe Uniwersytetu Ekonomicznego w Katowicach, 281, 57-66. 
de Jesus Pacheco, D. A., ten Caten, C. S., Jung, C. F., Ribeiro, J. L. D., Navas, H. V. G., \& Cruz-Machado, V. A. (2017). Eco-innovation determinants in manufacturing SMEs: Systematic review and research directions. Journal of Cleaner Production, 142, 2277-2287. https://doi.org/10.1016/j.jclepro.2016.11.049

Johnson, S., Webber, D. J., \& Thomas, W. (2007). Which SMEs use external business advice? A multivariate subregional study. Environment and Planning A, 39(8), 1981-1997. https://doi:10.1068/a38327

Keller, G. (2012). Statistics for management and economics. Mason: Cengage Learning.

Kołodziej-Hajdo, M., \& Surowiec, A. (2011). Finansowanie projektów MSP z funduszy unijnych: korzyści i bariery [Financing SME projects from EU funds: Benefits and barriers]. Zeszyty Naukowe Uniwersytetu Szczecińskiego. Finanse. Rynki finansowe. Ubezpieczenia, 32, 535-547.

Kopiński, D. (2011). Pomoc rozwojowa. Teoria i polityka [Development aid. Theory and policy]. Warszawa: Difin.

Lisowska, R. (2014). Wsparcie rozwoju małych i średnich przedsiębiorstw przez instytucje otoczenia biznesu na przykładzie usługodawców logistycznych w województwie łódzkim [Support for the development of small and medium enterprises by business environment institutions on the example of logistics service providers in the Łódzkie Voivodeship]. Ekonomia i Zarzadzanie, 6(2), 11-22.

Lisowska, R. (2017). Adekwatność oferty instytucji otoczenia biznesu do potrzeb W zakresie rozwoju małych i średnich przedsiębiorstw - doświadczenia przedsiębiorców z województwa łódzkiego [Suitability of business environment institutions' offer for the development needs of small and medium-sized enterprises experience of entrepreneurs from the Lodz region]. Przedsiębiorczość i Zarzadzanie, $18(1)$, pp. 263-275.

Lisowska, R., \& Stanisławski, R. (2011). Obszary i instrumenty wsparcia małych i średnich przedsiębiorstw w świetle badań na przykładzie województwa łódzkiego [Obszary i instrumenty wsparcia małych i średnich przedsiębiorstw w świetle badań na przykładzie województwa łódzkiego]. In M. Matejun (Ed.). Wspomaganie i finansowanie rozwoju matych $i$ średnich przedsiębiorstw [Supporting and financing the development of small and medium-sized enterprises] (pp. 288-306). Warszawa: Difin.

Marshall, A., Shaw, G., Murphy, D., Sena, V., Rosiello, A., Sena, V., Carr, C., Golra, O., \& Hickman, S. (2020, June). Knowledge absorption and innovation in UK SMEs: A pilot study by place and economic sector. Proceedings of the 2020 International University-Industry Interaction Conference. Amsterdam: UIIN. Retrieved from https://innovationcaucus.co.uk/2019/06/01/knowledge-absorption-and-innovation -in-smes-a-pilot-study-by-place-and-economic-sector/

Matejun, M. (2015). Absorpcja wsparcia w zarządzaniu rozwojem mikro, małych i średnich przedsiębiorstw - podejście strategiczne [Absorption of support in management of development of micro-, small and medium enterprises - strategic approach]. Zeszyty Naukowe. Rozprawy Naukowe, 483(1194). Łódź: Wydawnictwo Politechniki Łódzkiej. 
McCann, P., \& Ortega-Argilés, R. (2016). Smart specialisation, entrepreneurship and SMEs: Issues and challenges for a results-oriented EU regional policy. Small Business Economics, 46(4), 537-552. https://doi: 10.1007/s11187-016-9707-z

Mole, K., Hart, M., \& Roper, S. (2014). When moving information online diminishes change: advisory services to SMEs. Policy Studies, 35(2), 172-191. https://doi: 10.1080/01442872.2013.875145

Mole, K., North, D., \& Baldock, R. (2016). Which SMEs seek external support? Business characteristics, management behaviour and external influences in a contingency approach. Environment and Planning C: Politics and Space, 35(3), 476-499. https://doi:10.1177/0263774X16665362

Moritz, A., Block, J. H., \& Heinz, A. (2016). Financing patterns of European SMEs - an empirical taxonomy. Venture Capital, 18(2), 115-148. https://doi:10.1080/136910 66.2016.1145900

Muller, P., Devnani, S., Julius, J., Gagliardi, D., \& Marzocchi, C. (2016). Annual Report on European SMEs 2015/2016. SME recovery continues. Brussels: European Commission.

Nardi, P. M. (2018). Doing survey research: A guide to quantitative methods. Abingdon: Routledge.

Niemczyk, J. (2013). Ujęcia zarządzania strategicznego z perspektywy renty ekonomicznej [Imaging of strategic management from the perspective of an economic pension]. In R. Krupski (Ed.). Zarzadzanie strategiczne. Quo vadis? [Strategic management. Quo vadis?] (pp. 77-83). Wałbrzych: Prace Naukowe Wałbrzyskiej Wyższej Szkoły Zarządzania i Przedsiębiorczości.

North, D., Smallbone, D., \& Vickers, I. (2001). Public sector support for innovating SMEs. Small Business Economics, 16(4), 303-317.

Ozekicioglu, S. S., \& Yetiz, F. (2019). Financial supports provided to SMEs within the context of the European Union's budget. In Y. Bayar (Ed.), Handbook of research on social and economic development in the European Union (pp. 309-323). Hershey, PA: IGI Global. https://doi:10.4018/978-1-7998-1188-6.ch019

Peszko, A. (2013). Instytucje otoczenia biznesu wspierające rozwój MSP w Polsce [Business support institutions supporting the development of SMEs in Poland]. In R. Borowiecki \& B. Siuta-Tokarska (Eds.). Zarządzanie rozwojem współczesnej organizacji: uwarunkowania - innowacje - strategie [Managing the development of a modern organization: Conditions - innovations - strategies] (pp. 33-46). Kraków: Uniwersytet Ekonomiczny w Krakowie, Fundacja Uniwersytetu Ekonomicznego w Krakowie.

Peszko, A. (2014a). Micro-, small-, and medium-sized enterprises using structural funds. Managerial Economics, 15(1), 97-106. https://doi:10.7494/manage.2014.15.1.97

Peszko, A. (2014b). Regional institutions supporting entrepreneurship in lesser Poland. In J. Kaczmarek \& K. Kolegowicz (Eds.). Developmental challenges of the economy and enterprises after crisis (pp. 405-411). Krakow: Department of Economics and Organization of Enterprises, Cracow University of Economics. Foundation of the Cracow University of Economics. 
Popper, K. R. (2014). The logic of scientific discovery. Eastford: Martino Fine Books.

Prokop, V., \& Stejskal, J. (2019). Determinants of innovation activities and SME absorption: Case study of Germany. Scientific Papers of the University of Pardubice. Series D, Faculty of Economics and Administration, 46, 134-146

Radicic, D., \& Pugh, G. (2017). R\&D programmes, policy mix, and the 'European Paradox': Evidence from European SMEs. Science and Public Policy, 44(4), 497-512. https://doi:10.1093/scipol/scw077

Reips, U. D., \& Funke, F. (2008). Interval-level measurement with visual analogue scales in internet-based research: VAS Generator. Behavior Research Methods, 40(3), 699-704. https://doi:10.3758/BRM.40.3.699

Sarstedt, M., \& Mooi, E. (2014). A concise guide to market research. Berlin-Heidelberg: Springer-Verlag.

Sawicki, P. (2019), Rozwój MSP w kontekście unijnego wsparcia w perspektywie 20142020 - dylematy i wyzwania [SME development in the context of EU support in the 2014-2020 perspective - dilemmas and challenges]. Zeszyty Naukowe ZPSB. Firma i Rynek, 1(55), 49-64.

Szara, K. (2012). Bariery pozyskiwania środków unijnych i ich wykorzystywania w aspekcie cyklu życia projektu [Barriers to obtaining and using EU funds in the aspect of the project life cycle]. Nierówności Społeczne a Wzrost Gospodarczy, 27, 175-187.

The SME Performance Review data. (2016). Brussels: The European Commission. Retrieved from https://ec.europa.eu/growth/smes/business-friendly-environment/performancereview-2016_en

Vedovello, C., \& Godinho, M. (2003). Business incubators as a technological infrastructure for supporting small innovative firms' activities. International Journal of Entrepreneurship and Innovation Management, 3(1-2), 177-201. https://doi:10.1504/ IJEIM.2003.002215

Wach, K. (2004). Nowe kryteria klasyfikacji małego i średniego przedsiębiorstwa w ustawodawstwie unijnym [New criteria for the classification of small and medium-sized enterprises in EU legislation]. Ekonomika i Organizacja Przedsiębiorstwa, 5, 33-43.

Wach, K. (2008). Regionalne otoczenie matych i średnich przedsiębiorstw [Regional environment of small and medium enterprises]. Kraków: Wydawnictwo UE.

Wach, K. (2015). Modern policy for the entrepreneurial economy: Theoretical considerations. In K. Wach \& A. Gubik (Eds.) Institutional aspects of entrepreneurship (pp. 9-18). Miscolc: University of Miscolc.

Woźniak, M. (2012a). Znaczenie dotacji jako formy wspierania rozwoju małych i średnich przedsiębiorstw [The importance of grants as a form of support for the development of small and medium-sized enterprises]. In S. Szydło (Ed.). Wybrane zagadnienia społeczno-gospodarcze $w$ okresie transformacji rynkowej [Selected socio-economic issues in the period of market transformation] (pp. 205-222). Kraków: Wydawnictwa AGH. 
Woźniak, M. (2012b). System wspierania matych i średnich przedsiębiorstw $w$ Polsce [Support system for small and medium-sized enterprises in Poland]. Kraków: Wydawnictwa AGH.

Woźniak, M. (2014a). Business incubators as drivers for development of enterprises. In P. Łebkowski (Ed.). Zarzadzanie przedsiębiorstwem: teoria i praktyka [Business management: Theory and practice] (pp. 390-399). Kraków: Wydawnictwa AGH.

Woźniak, M. (2014b). Impact of business incubators upon development of enterprises. In M. Matejun (Ed.). Small and medium-sized enterprises in the European Union: Development challenges in 2014-2020 perspective (pp. 39-48). Lodz: Lodz University of Technology Press.

Woźniak, M. (2014c). Wspieranie przedsiębiorstw w dostępie do rynków zagranicznych [Supporting enterprises in accessing to foreign markets]. In A. Jabłonski \& M. Jabłoński (Eds.). Strategiczny wymiar modeli biznesu $w$ zarzadzaniu wartościa przedsiębiorstw - kierunki rozwoju [Strategic dimension of business models in managing the value of enterprises - directions of development] (pp. 511520). Dąbrowa Górnicza: Wyższa Szkoła Biznesu w Dąbrowie Górniczej. 